\title{
Realities of Graphic Novels: An Interview with Frederick Aldama
}

\author{
Interviewed by Ruzbeh Babaee \\ Faculty of Arts, University of Porto, Portugal
}

Received: -

doi:10.7575/aiac.ijclts.v.5n.3p.1
Accepted: -

Published: 31-07-2017

The trend about producing and reading graphic novels has grown since the late twentieth century. These books with comic backgrounds seem to have a miraculous energy. They have been even appealing to unenthusiastic readers. They tempt people of different age groups, races and genders. They are also used for teaching ESL courses, e-learning activities, designing reality games, and teaching creative writing. If you talk to its followers, you may get the feedback that graphic novels can fulfil your demands and dreams from writing your assignments to taking you to the moon. Although many researchers have investigated the benefits of graphic novels, many faculties and librarians are still reluctant to include graphic novels in their curricula. Perhaps it is simply the attitude of many teachers and librarians that graphic novels look like a comic book, and simply are not "real" books. They have too few words, too many pictures, and lack quality to be seriously considered as literature. In the following, I, Ruzbeh Babaee, did an interview with Distinguished Professor Frederick Luis Aldama on realities of graphic novels.

Aldama is a distinguished scholar and Professor of English at The Ohio State University, United States. In the departments of English and Spanish \& Portuguese he is involved in teaching courses on US Latino and Latin American cultural phenomena, literature, film, music, video games, and comic books. He has founded and directed the White House Hispanic Bright Spot awarded LASER/Latino and Latin American Space for Enrichment Research. Professor Aldama won the Ohio Education Summit Award for Founding \& Directing LASER in 2016. In April 2017, Aldama was awarded OSU's Alumni Award for Distinguished Teaching and inducted into the Academy of Teaching. He is the author, co-author, and editor of 30 books, including his first book of fiction/graphic fiction, Long Stories Cut Short: Fictions from the Borderlands.

\section{RB $^{1}$ : What inspired you to write and conduct research on graphic novels, video games, and comic books?}

FA $^{2}$ : Of course, as a person grown in a 1980s cultural soil quickly filling to the brim with innovative visual-verbal and visual-auditory-motor ways of engaging the imagination, one way or another I've always been invested in graphic novels, video games, and comic books. On an intuitive level during my undergraduate days at Berkeley as a literature major and then more systematically as a graduate student at Stanford, I began to clearly see that the line drawn between the literary artefacts deemed worthy of serious academic study and those less worthy like comic books and pop cultural phenomena generally was one drawn in sand. My light-bulb moment happened when I stumbled into the advances in cognitive science - especially those insights coming from scholars working in the areas of early cognitive development. That the exercising of our causal and counterfactual reasoning processes allow us to spin out of ourselves (like a spider) all variety of cultural phenomena that these creators invite people like me and you to engage with and to exercise our co-creative capacities. In a video game (and there are different kinds, from puzzle solving to first-person shooters) uses an algorithm built out of audio and visual components and that require our doing (motor cortex) for the co-creating to take place, the games work by inviting us to gap fill and stitch ourselves into the narrative. The same with comics and then the longer graphic novel form, of course using it's own set of visual and verbal narrative shaping devices to pull us in. No matter the format or type (alphabetic, visual-verbal, audio-visual, and so on) as I became more deeply interested in how we create and co-create all cultural phenomena, the more I realized that any distinction between high and low brow was specious. Now, this isn't to say that all cultural phenomena are created equal. Indeed, there are some artefacts or products that do not aim to make new our perception, thought, and feeling about the world. But this is the case in all cultural products, from literature to music to film to comics. For me, then, debating the lowbrow vs. highbrow is less interesting than the constant search to deepen understanding about how creation and co-creation work, especially in understudied cultural phenomena identified as US Latino and Latin America.

\section{RB: Did Latin American critical cultural theory play an important role in your inspiration?}

FA: Thank you for this question, Ruzbeh. In graduate school, Beatriz Sarlo, Ángel Rama, and Néstor García Canclini threw wide open the doors to ways one could analyse Latin American pop cultural phenomena. Indeed, it was the discovery of Cuban scholar Fernando Ortíz Fernandez's notion of transculturation in the convergence of cultures; that

\footnotetext{
${ }^{1}$ Ruzbeh Babaee

${ }^{2}$ Frederick Aldama
} 
the movement of popular cultural forms across national, cultural, linguistic borders creates something entirely new. During this period, too, the cultural studies work of Graeme Turner and Paul Gilroy proved important; like Ortíz Fernandez, they, too were deeply interested in how pop cultural forms transculturated as they traversed socioeconomic, racial, and other borders. They showed me that one could embark on a journey dedicated to the scholarly study of pop cultural phenomena. This said, I knew all along that they would exist as inspirations - and not as methodological models. I've always been deeply interested in clarifying the difference between the ontological, epistemological, and functional. Put simply, I wanted to articulate an approach and method that would not collapse these three levels (ontological, epistemological, and function) in the study of pop cultural phenomena; that I would keep these three levels in mind as distinctively different all while keeping in mind the dialectic of us as creators and co-creators of pop cultural phenomena. Put simply, a Latino comic book is the distillation and reconstruction of the building blocks of reality and exists as an addition to reality, and not a mirror in the road or simulation of reality. This object is given a particular visual-verbal narrative shape that we can work on, teach, and understand in ways. Our study of this object can and does allow us to formulate hypotheses concerning how it aims to engage its respective ideal audiences - and in many cases wake these audiences to knew ways of perceiving, thinking, and feeling about the world.

\section{RB: What is your definition of graphic novels? Do you see any boarders between literature and graphic novels?}

FA: Ruzbeh, as you know there's a lot of critical (scholarly and mainstream) on this topic of the graphic novel—and what defines it. For me it's a material history and an aesthetic configuration. During the 1990s when I was finally able to return to comics and begin to study them within the context of the university (albeit in a very nascent way) I began to see "graphic novel" mentioned in course syllabi and in the aisles of Barnes \& Nobel and Borders bookstores. At first, I scratched my head with this seeming rechristening of the format I'd known as comic books since a kid when I'd save my nickels to buy comics at the 7/11 or Circle K down the road. Then I realized that creators like Alan Moore, Neil Gaiman, Mike Mignola, Todd McFarlane, Chris Ware, Art Spiegelman, Jeff Smith, and, of course, Los Bros Hernandez were creating narratives with big arcs; the kind we'd already seen with Möbius and Hergé in France as well as Carlos Trillo and Héctor Germán Oesterheld in Argentina, among many others. That is, even if these creators were still publishing single-issue comics, they had in mind big character arcs that would realize themselves once collected and published as a single volume; what the publishers were calling graphic novels. In my interviews with Jaime and Gilbert Hernandez they speak to this directly, mentioning how Fantagraphics was making the real money once the separate issues were collected and sold in a single book; they also mention how this constraint, say, did influence the way they conceived of the single issue comic. We see this today with the mainstream superhero comics, too. DC and Marvel continue to sell single-issue comics that then become sold as book volumes later down the line. The marketplace has given shape to new ways of conceiving the comic - and all under the rechristened identifier: graphic novel.

I should add, too, that when "graphic novel" first began appearing on classroom syllabi it did so within departments that had traditionally been teaching alphabetic literature. What better way to smooth the swallowing of this pill for many of our suspecting senior colleague than to call it "graphic novel". While we've certainly made huge strides forward - and The Ohio State University is a bastion for comic book studies - many of us still have to justify the teaching of comic books - even if calling it "graphic novel". In fact, I advise my graduate students to not write dissertations committed exclusively to the study of comics; their dissertations include comics, but also alphabetic literature. And, when they are out hunting for jobs, I advise them not to present their work on comics as their job talk. The academy is still trying to wrap its head around the fact that the comic book/graphic novel can be just as sophisticated a narrative form as an alphabetic novel; that Gilbert Hernandez's Palomar is as complex and layered and transformative as Gabriel García Márquez's 100 Years of Solitude.

\section{RB: Is "graphic novels" a genre using a combination of words and pictures to convey a narrative?}

FA: Just to reiterate, the graphic novel is the comic book conceived of as the building of a stretched story arc and kinesis of character consciousness that coheres over dozens of pages; this can happen with the collecting of a series of single-issued comics (typically 32 pages) or in the creating of the graphic novel from A to $\mathrm{Z}$ as a single book. In either the case of the single issue(s) that have their own self-contained narrative arcs that unfold over 32 pages or the longer format, both rely on both visual and verbal devices to give shape their narratives. This said, in my book, Your Brain on Latino Comics I argue that when the verbal devices become too dominant and where they work as a kind of crutch to support the visuals, then the comic book/graphic novel becomes something else like an illustrated story. And, in my latest book, Latinx Superheroes in Mainstream Comics, I formulate a geometric approach. I argue that in their careful geometrizing of shapes like circles, triangles, and lines of perspective generally, creators can and do dynamically convey complex character interior states of mind and behaviour within richly constructed storyworlds. Indeed, based on a geometric approach to analysing comic books/graphic novels we can and should evaluate whether some more than others wake us to new ways of seeing, thinking, and feeling about ethnoracialized subjects (Latinos) in the world.

\section{RB: Isn't "graphic novels" a form that can be fallen into any genre (Comedy, Historical Fiction, Realistic Fiction, utopian/dystopian fiction, etc.)?}

FA: I'm so glad you put front and centre this question about genre, Ruzbeh. In the mainstream and academe there can be a too easy conflation of form or media with genre. Creators of graphic novels and narrative fiction generally not only 
work within the constraints of genre, but also actively cross-pollinate genres with their creations. They also recreate from other forms or media, like alphabetic literature, film, and art. When Peter Kuper chooses to recreate Kafka's Metapmorphosis he chooses from a whole range of comic book geometric shaping devices (panel size and layout, gutter placement and thickness, circle, triangle, rectangular shape, angle of view, and so on) to distil and reconstruct from the alphabetic narrative. In so doing, he also transforms the story into something new-something that stands on its own two legs without the need of the Kafka original. The question to ask ourselves is: what is the degree of intentionality present in the distillation and reconstruction of, say, the Kafka alphabetic text into the Kuper comic book. Examples may be multiplied without end, particularly if we go from an alphabetic text to an inseparable mix of image and text (comic books, etc.) and then to film and even ballet and other forms of dance, of certain forms of gymnastics and even pure music.

\section{RB: How do you see the place of graphic novels in academic curricula, especially in literature curricula?}

FA: Thank you for returning us to this point, Ruzbeh. We're seeing across the country more and more departments of literature incorporating graphic novels into their curriculum. However, only a few such departments have courses on the books that are devoted exclusively to the study of comic books/graphic novels; I feel rather lucky to be teaching in a department where we have a pop culture studies minor and courses on the books dedicated to comic book studies. What we generally tend to see are syllabi where there's a graphic novel or two mixed in with a dominant corpus of alphabetic texts. Let me add that with the teaching of graphic novels/comic books within literature departments we tend to see the overlaying of analytic models grown from alphabetic literary studies that give short shrift to the visual shaping devices. It's why, I suspect, Maus and Fun Home have become main staples of English department curricula. They are more identifiably "literary" in their verbal compositions and themes. In my courses on comics, to be sure the students attend to the wondrous ways that the visuals give shape to the narrative I put front and centre Stan Lee's How to Draw Comics and Will Eisner's Comics and Sequential Art.

\section{RB: Does "graphic novels" offer a new model/approach for teaching creative writing?}

FA: When teaching my courses on comics and also courses that include comics such as Latinx Pop Culture, I give the students time in class to create a one-page autobiographical comic. Whether it's a student who does so with stick figures or one with, say, greater realism, they all quickly realize how difficult it is to distil and recreate a moment in their lives with the devices used for comic book storytelling. Of course, this intensifies their appreciation of the artfulness of comics; those who might have considered it a lesser form of storytelling no longer do so. And, with more students reading less alphabetic literature and viewing more narratives through smartphones and so on, it offers them a visual means of rather efficiently distilling and reconstructing watershed moments in ways that immediately move the other students; I take pictures of the works then put them up on a PowerPoint and ask the students to respond. We distil and recreate the building blocks of reality in alphabetic fiction, too. And, of course, creative writing classes workshop this kind of narrative, offering feedback on its distinctive set of shaping devices such as, say, the use of free indirect discourse. It's the same with teaching comics. The students learn of their own power to tell and show stories. They learn of their own power to materialize their voice - and this is especially important for Latino students who have been traditionally silenced in the academic and mainstream spaces.

\section{RB: How do you see the future of graphic novels?}

FA: I'm optimistic about the creation of cultural phenomena generally, Ruzbeh. Creators continue to struggle, of course. And, the planet's social tissue generally seems to disallow more and more children from having access to the kinds of emotive and cognitive tools necessary for the realization of their full potentials. I have created high school programs that open doors for new generations of Latino creators - whether of graphic novels or scientific hypotheses; I've established the Latinographix trade-press book series to publish our creators. In this way, I remain optimistic for us as a species - and the kind of narrative art we will create and innovate. We will continue to create graphic novels that make new our senses, thoughts, and feelings about the many different slice of planetary reality that make up our experiences and subjectivities. I can't wait to see what tomorrow will bring.

RB: In 2017, you were awarded Alumni Award for your distinguished teaching. Please briefly explain criteria that you have included and introduced in your teaching approach.

FA: I regularly teach courses (at all levels) that are cross-listed across the English, Comparative Studies, Spanish \& Portuguese, and Film Studies Departments. While the primary objects of investigation are by and about Latina/os and/or focused on literature, comics, and film writ large, I have my students think deeply about how a given creator gives generative shape to issues of race, class, disability, and sexuality. Often in the classroom and assigned readings, I help deepen students' understanding of how the emotive and cognitive processes work in making and engaging with the respective narrative media; for this reason, many students majoring in psychology and neuroscience take my courses. Whether we analyze a comic by Jaime Hernandez, or a Christopher Nolan Batman film, my goal is for students to learn how the creator distills and reconstructs from the building blocks of reality in ways that generate new thoughts, feelings, and actions. 
This huge honor of receiving such a distinguished award and being inducted into the Academy of Teachers also spins out of something I already mentioned earlier in the interview: the drive to offer the conceptual and material tools for future generations of Latino/as to be able to realize their full potentialities. In 2009, I created LASER: Latin \& Latin American Space for Enrichment \& Research. LASER has built community on campus by working with communities off campus - Latina/o graduate students work with Latina/o undergraduates on campus, and both groups work with Latina/o high school students in the wider community. With LASER Hubs in schools and libraries across the greater Columbus area, and with virtual hubs reaching rural Latina/o Ohioans, every student in the program successfully makes it to OSU (or a LASER partner college) and then thrives once in college. LASER has grown from serving 5 Latina/o students to over 300 today. One of LASER's signature yearly events is SÕL-CON. I bus in K-12 Latino/a and African American students to meet and learn firsthand from some our most creative Latina/o and African American makers of comic books, Zines, and digital animation. This event provides a time for learning and for exploring different aspects of themselves, and a space for healing between Latina/o and African American communities. It also offers graduate and undergraduate students on campus opportunities to curate, organize, interact with, and network with scholars and artists of color locally and nationally.

\section{RB: And, finally, what projects are you working on at the moment?}

FA: I'm currently putting the finishing touches on two projects relating to comics: World Comics: The Basics (Routledge) and The Latinographix Collection (OSU Press). Let me mention a little about this collection. I bring together sixty-seven of our Latino/a creators. Their respective short visual-verbal narratives spring from their particular Latino/a as well as universal experiences informed by their specific identities and subjectivities. Their carefully crafted visual-verbal narratives showcase the huge variety of styles and worldviews most Latino/a comic book creators are developing. Taken individually and together, the sixty-seven creators and their works show the world that when it comes to Latino/a short visual-verbal narratives, content and form no longer impose any limits. In fact, these categories in their dichotomous appearance now turn out to be superfluous. In each narrative "form" (geometry) flows into "content" (story), and vice versa. Each artist makes distinctive use of space design, inking, lettering, balloon size, shape and placement, perspective and geometric storytelling. Indeed, as we travel from one story to the next we experience the unique ways that each creator (or set of creators) has chosen to geometrize their story, and storify their chosen geometry (figures, shapes, sizes, structures). Thus our hearts and minds wake to the complex work that Latino/as artists produce while we also learn how to see our world through the narratives and the visual artworld they have created. This apprenticeship in Latino/a visual storytelling includes finding our way to and through singular or multiple languages, proximate and distant histories, as well as gender, sexuality, and class marked spaces. Some of the Latino/a creators included here chose to convey their visual-verbal narratives within a recognizably tellurian present, while others chose different planetary and mythically dimensioned time-spaces. Whether helping or not to shape our complex kinesis of consciousness when we are growing up as a mono- or bilingual, bicultural, straight, queer, macho, feminist Latino/a, these comic book vignettes deal always with the expansive complexity of our identities, the multiplicity of our circumstances and the cultural richness of our experiences. They show the world that Latino/a comic book creators are at once giving unique geometric shape to particular stories involving Latino/a identities and communities, and are at the time creating unique stories in fusion with their correspondingly unique geometries. Through their work, these creators are actively adding to and transforming our planetary republic of comics.

I'd like to wrap up this interview by mentioning how as Latino/a producers and as consumers of comics, our numbers are growing steadily. And the creative imagination of our narrative-visual practitioners is penetrating all geographies, all social and historic settings, all human experiences, thereby reaching into and modifying all previous storyworlds and genres made possible by the new cultural and demographic circumstances.

\section{References}

Aldama F. L. (2017). The Art of the Matter: Interviews with Latino/a Children's \& Young Adult Fiction Authors. Pittsburgh: University of Pittsburgh Press

Aldama F. L. (2017). Latinx Superheroes in Mainstream Comic Book Storyworlds: Toward a History and Theory. Tucson: University of Arizona Press

Aldama F. L. (2017). Long Stories Cut Short: Fictions from the Borderlands. English \& Spanish. Fiction. Tucson: University of Arizona Press (Camino del Sol Series)

Aldama F. L. (2017). The Routledge Companion to Latino/a Pop Culture. Ed. New York: Routledge, 2016.

Aldama F. L. (2017). Latinx Comic Book Storytelling: An Odyssey by Interview. San Diego State University Press,

Aldama F. L. (2016). "Restless and Relentless in Graphixlandia: A Foreword”. Rendez-Vous in Phoenix.

Graphic novel by Tony Sandoval. Magnetic Press

Aldama F. L. (2014). “A Scientific Approach to the Teaching of a Flash Fiction.” Interdisciplinary Literary

Studies: A Journal of Criticism and Theory. 16 (1): 127-144. 